\title{
Location-Routing Problem Analysis (Case Study: Natural Disaster Risk Mitigation in Pangandaran District)
}

\author{
Nabila Fajri Kusuma Ningrum, Muhammad Welano Kharisma, Rifqi Rahmadanti Agustin, Anak Agung Ngurah \\ Perwira Redi, and Rahmad Inca Liferda \\ Department of Logistics Engineering, Universitas Pertamina, Jalan Teuku Nyak Arief, Jakarta, Indonesia \\ e-mail: nabilafajrikusumaningrum@gmail.com
}

\begin{abstract}
Geographically, Indonesia is surrounded by three continental plates which cause the emergence of earthquake pathways, a series of active mountains throughout Indonesia, and the inevitable tsunami. Considering the large potential and risks arising from such natural disasters, disaster mitigation is important to minimize the risk, one of which is through humanitarian logistics. Pangandaran Regency is the focus of this study given that in 2018, Pangandaran is the 16th most disaster-prone area out of 514 districts/cities in Indonesia and the 5th out of 27 districts/cities in West Java. It would be a high risk if mitigation, preparation, and logistics response in Pengandaran is not well planned. The focus of this research is to determine the strategic location of disaster emergency response warehouse placement with the Set Covering Problem algorithm and determine the optimal route to the location of refuge using the Nearest Neighborhood Heuristics, Local Search, and Simulated Annealing algorithms.
\end{abstract}

Keywords-Humanitarian Logistics, Analytical Network Process, Local Search, Simulated Annealing.

\section{INTRODUCTION}

INDONESIA is geographically surrounded by the Pacific Ring of Fire which is shaped like a horseshoe along the islands of Sumatra, Java and Sulawesi. In addition, the location of Indonesia which is in the confluence of three continental plates including Indo-Australia from the south, Eurasia from the north, and the Pacific from the east which makes Indonesia in the path of the most active earthquake in the world. This causes the Indonesian region prone to disasters ranging from volcanic eruptions, earthquakes and tsunamis. Tsunamis can be indentified as one of the deadliest natural disasters and create enormous losses for coastal residents. Tsunamis can be caused by earthquakes or sea floor disturbance that causes sea water instability.

One area in Indonesia which has a high level of tsunami threat is the Pengandaran District, which is classified as a very risky area because the earthquake and tsunami often happened around the southern coast of Java. According to LIPI, this disaster is difficult to predict. According to Endra Gunawan's research results and the team from the Institut Teknologi Bandung (ITB), there is still a deformation movement in the epicenter area due to the tsunami which has the potential to trigger further earthquakes.

Disaster mitigation is the initial action which very necessary in order to minimize the risk of losses caused by tsunamis that are predicted to occur without warning, as the loss of life, material, mental and environmental losses can be minimized and controlled. Disaster mitigation is a key of success in emergency disaster management if it is combined
Table 1.

Sub-District Code

\begin{tabular}{cc}
\hline \multicolumn{2}{c}{ Sub-District Code } \\
\hline \hline Code & Sub-District \\
\hline A & Kalipucang \\
B & Cimerak \\
C & Cijulang \\
D & Cigugur \\
E & Parigi \\
F & Langkaplancar \\
G & Sidamulih \\
H & Pangandaran \\
I & Mangunjaya \\
J
\end{tabular}

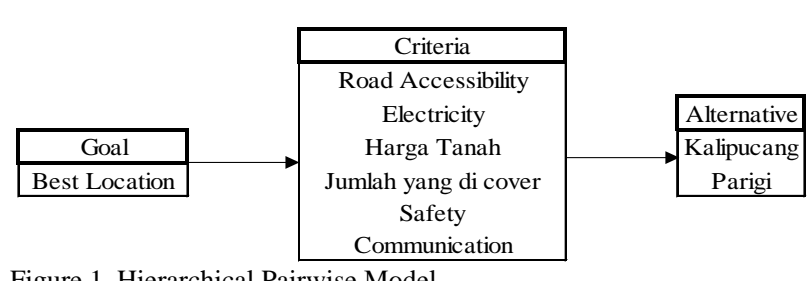

Figure 1. Hierarchical Pairwise Model.

by preparation and a responsive and mature implementation [1]. This study aims to find the most optimal route for channeling inventories from emergency response warehouses to all affected sub-districts as a basis for mitigation as the distribution of inventories to meet primary needs right after the disasters occur can be done quickly, effectively, and accurately.

\section{RESEARCH METHODOLOGY}

This research will be presented with mathematical equations in determining the location of strategic emergency response warehouses and the most optimal route for channeling inventories from warehouses to sub-districts in Pengandaran that are affected by disasters. This mathematical model consists of two phases. The first phase uses the Set Covering Problem and Analytical Network Process methods in deciding the number and location of emergency warehouses needed to cover the entire sub-district in Pengandaran. While the second phase uses the Vehicle Routing Problem with Nearest Neighbor Heuristics, Local Search, and Simulated Annealing methods to compare the best routes that can minimize travel time from the emergency warehouse to the affected sub-districts in Pengandaran.

The assumptions used in this study include:

1. Demand is considered as the number of families in each district.

2. The government aims to build only 1 warehouse 
The 8th International Conference on Transportation \& Logistics (T-LOG 2020)

Surabaya September 6th-7th 2020, Universitas Internasional Semen Indonesia (UISI), Gresik, Indonesia

Table 2.

Distance between Sub-Districts in Pangandaran

\begin{tabular}{|c|c|c|c|c|c|c|c|c|c|c|c|}
\hline $\begin{array}{c}\text { Sub- } \\
\text { District }\end{array}$ & 0 & A & B & $\mathrm{C}$ & $\mathrm{D}$ & $\mathrm{E}$ & $\mathrm{F}$ & G & $\mathrm{H}$ & I & $\mathrm{J}$ \\
\hline 0 & . & 4 & 58 & 40 & 47 & 36 & 67 & 27 & 18 & 25 & 22 \\
\hline A & 4 & . & 55 & 37 & 45 & 33 & 64 & 24 & 16 & 25 & 21 \\
\hline $\mathrm{C}$ & 40 & 37 & 19 & . & 17 & 15 & 37 & 24 & 23 & 64 & 60 \\
\hline $\mathrm{D}$ & 47 & 45 & 25 & 17 & . & 12 & 19 & 26 & 31 & 53 & 68 \\
\hline $\mathrm{E}$ & 36 & 33 & 33 & 15 & 12 & . & 31 & 15 & 19 & 42 & 57 \\
\hline G & 27 & 24 & 42 & 24 & 26 & 15 & 45 & . & 10 & 51 & 48 \\
\hline $\mathrm{H}$ & 18 & 16 & 41 & 23 & 31 & 19 & 50 & 10 & . & 42 & 39 \\
\hline I & 25 & 25 & 82 & 64 & 53 & 42 & 58 & 51 & 42 & . & 16 \\
\hline $\mathrm{J}$ & 22 & 21 & 78 & 60 & 68 & 57 & 66 & 48 & 39 & 16 & . \\
\hline
\end{tabular}

Table 3.

Criteria for Disaster Emergency Response Warehouse

\begin{tabular}{ll}
\hline \hline \multicolumn{1}{c}{ Criteria } & \multicolumn{1}{c}{ Description } \\
\hline Road Accessibility & $\begin{array}{l}\text { The location of the warehouse must be accessible by the mode of transportation so that } \\
\text { shipping to the warehouse and from the warehouse can be allocated } \\
\text { The electricity network is needed for the selection of warehouse locations to operate } \\
\text { electrical equipment and warehouse lighting } \\
\text { To see the ability of funds from BNPB } \\
\text { The more districts that can be covered by a warehouse, the better the location of the } \\
\text { Harga Tanah }\end{array}$ \\
$\begin{array}{l}\text { Jumlah yang di cover } \\
\text { Safety }\end{array}$ & $\begin{array}{l}\text { Safe and strategic warehouse locations from areas affected by natural disasters } \\
\text { Fast, precise, and efficient communication to provide the latest information to determine }\end{array}$ \\
\hline \hline
\end{tabular}

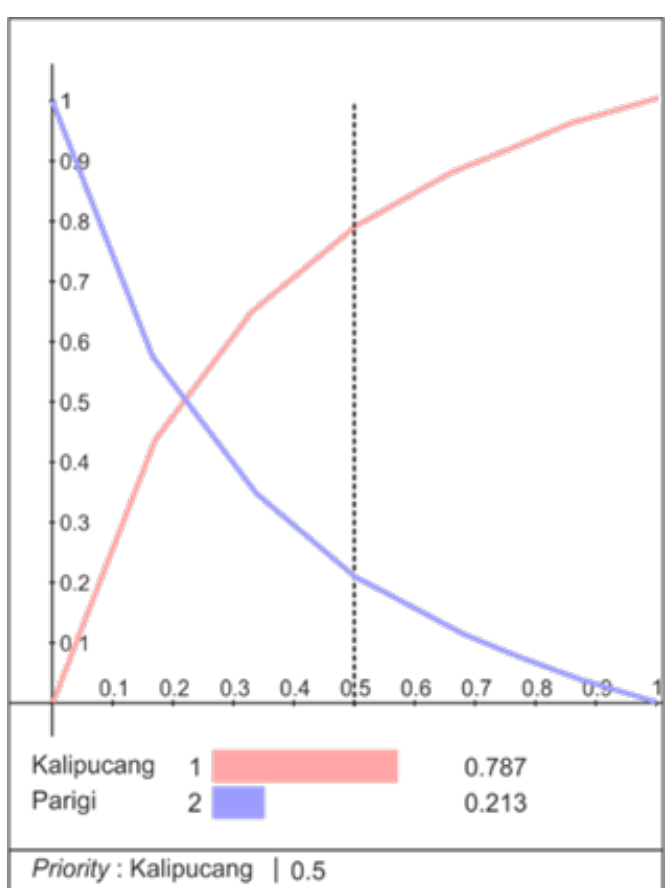

Figure 2. Sensitivity Test.

3. Distribution fulfills $5 \%$ of every family in each sub-district

4. Maximum capasity of the vehicle is 2200 boxes.

5 . Box with a size of $35 \times 20 \times 24 \mathrm{~cm}$ which can include medicine and food inside.

6. Vehicle speed of $60 \mathrm{~km} / \mathrm{hour}$.

\section{DATA}

The data needed to support the methods that will be used starts from the selection of candidates for disaster emergency warehouse locations by considering the distance for each sub-district. Data is taken from the website of Pangandaran District and the distance of each districts is measured through Google MyMaps [2][3]. Alternatives to the

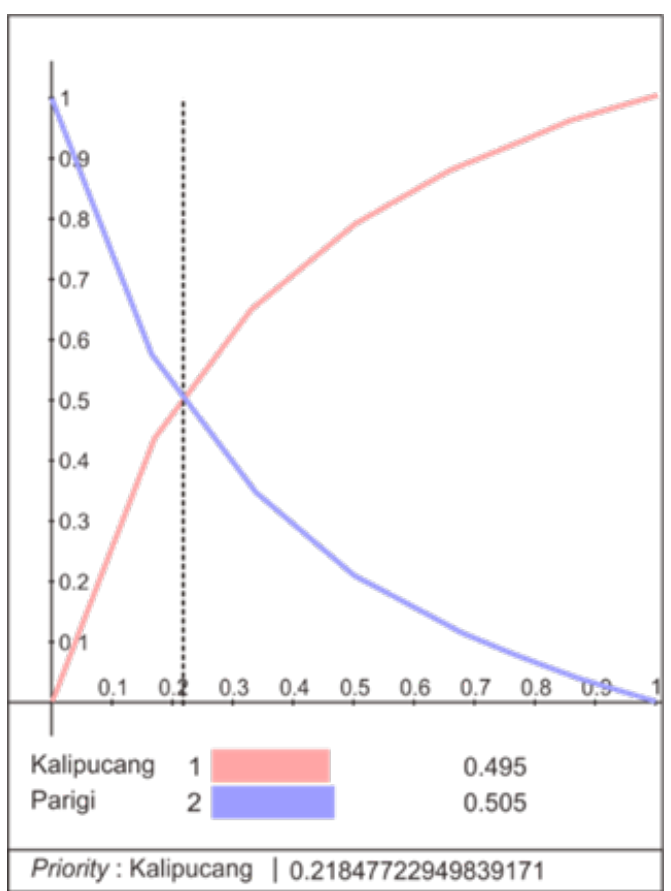

Figure 3. Change in Priority Order.

warehouse location in each sub-district of Pangandaran as shown on Table 1 and 2:

The selecting criteria for the location of disaster emergency warehouse are adopted from the criteria used to select a disaster emergency warehouse in Cilacap [4]. (Table 3)

After determining several criteria consideration in the selection of disaster emergency warehouse locations, the next step is to determine the priority of which criteria are most important to consider. Based on previous research assumptions and data, the first priority is security from the impact of disasters. The disaster emergency warehouse must be located in a location that is sterile from the impact of the disaster because if it is placed in an area close to disaster-prone areas, it is feared that the emergency 
The 8th International Conference on Transportation \& Logistics (T-LOG 2020)

Surabaya September 6th-7th 2020, Universitas Internasional Semen Indonesia (UISI), Gresik, Indonesia

Table 4.

Final Weight Results

\begin{tabular}{cccc}
\hline \hline Sub-District & Ideals & Normals & Raw \\
\hline Kalipucang & 1 & 0.630224 & 0.315112 \\
Parigi & 0.586738 & 0.369776 & 0.184888 \\
\hline \hline
\end{tabular}

Table 5.

Warehouse Priority Result

\begin{tabular}{ccc}
\hline \multicolumn{3}{c}{ Warehouse Priority Result } \\
\hline \hline \multirow{2}{*}{ Sub-District } & $\begin{array}{c}\text { Normalizes by } \\
\text { Cluster }\end{array}$ & Limiting \\
\hline Kalipucang & 0.60205 & 0.301025 \\
Parigi & 0.30795 & 0.198975 \\
\hline \hline
\end{tabular}

warehouse will be damaged and lose its main purpose. The second priority is the number of regions or sub-districts covered by the warehouse in order to maximize the number of sub-districts in Pengandaran that can receive the inventories. The third priority is the quality of road access, indicating easier access to transportation to deliver inventories to warehouses. Electricity is the fourth priority. The fifth priority is the flow of communication. While the last criterion is the price of land to minimize the costs for the construction of the emergency warehouse.

A. First Phase: Set Covering Problems and Analytical Network Process.

Set covering is used to determine the extent of each existing warehouse candidate [5]. The warehouse candidates are in each sub-district in Pangandaran District. Then, the distance data between sub-districts in Pangandaran Regency becomes input to get some alternative warehouse that can cover all districts. Then the results of this Set Covering Problems become input data in weighting process through Analytical Network Process.

The method of Set Covering Problem formulated as follows:

Minimize $\quad \sum_{(\mathrm{j} \in J)} \mathrm{X}_{\mathrm{j}}$

Subject to $\quad \sum_{(j \in J)} a_{i j} X_{j} \quad \geq 1 \quad \forall i \in I$

$$
X_{j} \in\{0,1\} \quad \forall i \in J
$$

$\mathrm{X}_{\mathrm{j}}=$ is value 1 to decide to opening the $\mathrm{j} \in \mathrm{J}$ facility, and otherwise 0

$a_{i j}=$ value 1 if the candidate of the $j \in J$ facility covers the demand at node $i \in I$, and otherwise 0 [6].

The objective function (1) is to minimize the travel distance (2) ensures that all demand on node $i$ is served by at least 1 facility, while equation (3) ensures that the value of the decision variable has a binary value of 0 or 1 .

Whereas Analytical Network Process is a general form of multi-criteria Analytical Heuristics Process for decision making. Analytical Network Process is a process that allows to enter all the factors or criteria that are tangible or intangible to make the best decision.

Analytical Network Process in pairwise comparison is done with a matrix and priority vectors by solving the equation:

$\mathrm{A} \times \mathrm{w}=\lambda \max \times \mathrm{w}$

$\mathrm{A}=$ pairwise comparison matrix

$\mathrm{w}=$ Eigen vector

$\lambda \max =$ biggest eigen value of $\mathrm{A}$

In Analytical Network Process, the first step is to create a pairwise hierarchical model with Super Decision software. The model consists of 3 levels. The first level is the level of objectives to be achieved, then the second is the criteria of the objectives and the last level are several alternatives available. Figure 1 is a pairwise hierarchical picture.

The second step is to rate the comparison between criteria,
Table 6.

Criteria Priority Result

\begin{tabular}{ccc}
\hline \hline Criteria & $\begin{array}{c}\text { Normalizes by } \\
\text { Cluster }\end{array}$ & Limiting \\
\hline Road Accessibility & 0.12115 & 0.301025 \\
Electricity & 0.09403 & 0.198975 \\
Harga Tanah & 0.04633 & 0.060575 \\
Number of Coverage & 0.2758 & 0.047017 \\
Safety & 0.42071 & 0.210356 \\
Communication & 0.04197 & 0.020984 \\
\hline \hline
\end{tabular}

and weights between alternatives based on existing criteria, weights made by the author based on the analysis of existing literature data. It aims to determine the consistency ratio for each weight of interrelated elements. The weight ratio of each element must be smaller than 0.1 to ensure that the weight is consistent.

Sensitivity analysis aims to anticipate changes that have been made before and measure the the stability of alternatives that have been prioritized. Vertical lines indicate the weight value of each alternative. In Figure 2, with a weight of 0.5 , the alternative priority is Kalipucang sub-district. But if the weight is reduced to 0.2185 as in Figure 3 , the alternative priority will change to Parigi sub-district.

B. Second Phase: Nearest Neighbor Heuristics, Local Search, and Simulated Annealing.

This method is a variation of the basic Vehicle Routing Problem model where Vehicle Routing Problem performs the most optimal route design for each vehicle in delivering goods. Since the problems are very complex, it has many variances to accommodate this complexity. The simplest model of Vehicle Routing Problem considers a set of customers or points of demand in an area. Each customer is associated with a demand that needs to be deliver as customer's location. The capacity of the vehicle to transport demand is also known.

Inputs

$\mathrm{N}$ Set of nodes where $\{1, \ldots, \mathrm{n}\}$ are customers and 0 is a depot

$\mathrm{C}_{\mathrm{ij}} \quad$ Distance from node I to $\mathrm{j}$ where $(\mathrm{i}, \mathrm{j}) \in \mathrm{N}$

$\mathrm{K} \quad$ Number of vehicles

Cap Vehicle capacity

$\mathrm{d}_{\mathrm{i}} \quad$ Demand of customers i where $\mathrm{i} \in \mathrm{N}$

Decision Variables

$\mathrm{X}_{\mathrm{ij}}\{(1,0)\}$ One if node arcs $(\mathrm{i}, \mathrm{j})$ is appears in the optional tour, Otherwise zero

$\mathrm{u}(\mathrm{i})_{\text {uj }}$ Variables that being used to apply the subtour elimination

Models

Minimize $\quad \sum(\mathrm{i} \in \mathrm{N}) \Sigma(\mathrm{j} \in \mathrm{N}) \mathrm{c}_{\mathrm{ij}} \mathrm{X}_{\mathrm{ij}}$

Subject to:

$$
\begin{array}{lc}
\sum(\mathrm{i} \in \mathrm{N} ; \mathrm{i} \neq \mathrm{j}) & \mathrm{X}_{\mathrm{ij}}=1 \\
\sum(\mathrm{j} \in \mathrm{N} ; \mathrm{i} \neq \mathrm{j}) & \mathrm{X}_{\mathrm{ij}}=1 \\
\sum(\mathrm{j} \in \mathrm{N} \backslash\{0\}) & \mathrm{X}_{0 \mathrm{j}} \leq \mathrm{K}
\end{array}
$$

$\mathrm{u}_{\mathrm{j}}-\mathrm{uI}+\mathrm{Cap}^{*} \mathrm{X}_{\mathrm{ij}} \leq$ Cap- $\mathrm{d}_{\mathrm{i}} \quad \mathrm{i} \neq \mathrm{j} ; \forall \mathrm{j} \in \mathrm{N} \backslash\{0\} ; \forall \mathrm{i} \in \mathrm{N} \backslash\{0\}$

$$
\begin{array}{cr}
d_{i} \leq u I \leq C a p & \forall i \in N \backslash\{0\} \\
u_{i} \geq 0 ; u_{j} \geq 0 & \forall i \in N, \forall j \in N
\end{array}
$$

To deliver intentories, the vehicle started its journey from a starting point which is intended to be a disaster emergency warehouse. The routes for Vehicle Routing Problem are 
The 8th International Conference on Transportation \& Logistics (T-LOG 2020)

Surabaya September 6th-7th 2020, Universitas Internasional Semen Indonesia (UISI), Gresik, Indonesia

Table 7.

Route using Nearest Neighborhood Heuristics

\begin{tabular}{cl}
\hline \multicolumn{1}{c}{ No } & \multicolumn{1}{c}{ Route } \\
\hline Route 1 & Warehouse - Kalipucang - Pangandaran - Sidamulih - Warehouse \\
Route 2 & Warehouse - Padaherang - Mangunjaya - Warehouse \\
Route 3 & Warehouse - Parigi - Cigugur - Cijulang - Warehouse \\
Route 4 & Warehouse - Cimerak - Langkaplancar - Warehouse \\
Distance & \\
\hline \hline
\end{tabular}

Table 8.

Route using Simple Local Search

\begin{tabular}{ll}
\hline \hline \multicolumn{1}{c}{ No } & \multicolumn{1}{c}{ Route } \\
\hline Route 1 & Warehouse - Kalipucang - Sidamulih - Pangandaran - Warehouse \\
Route 2 & Warehouse - Padaherang - Mangunjaya - Warehouse \\
Route 3 & Warehouse - Parigi - Langkaplancar - Cigugur - Warehouse \\
Route 4 & Warehouse - Cimerak - Cijulang - Warehouse \\
Distance & 369 \\
\hline \hline
\end{tabular}

Tabel 9.

Route using Simulated Annealing

\begin{tabular}{ll}
\hline \hline \multicolumn{1}{c}{ No } & \multicolumn{1}{c}{ Route } \\
\hline Route 1 & Warehouse - Kalipucang - Pangandaran - Warehouse \\
Route 2 & Warehouse - Padaherang - Mangunjaya - Warehouse \\
Route 3 & Warehouse - Parigi - Langkaplancar - Cigugur - Warehouse \\
Route 4 & Warehouse - Cijulang - Cimerak - Sidamulih - Warehouse \\
Distance & 362 \\
\hline \hline
\end{tabular}

those that meet the demand of all sub-districts in Pengandaran that are affected by disasters. Where each district is assumed to be visited once. Then after the last delivery on a route, the vehicle return to the warehouse.

The objective function to be achieved is to find the routes that have the least cost, where the cost component is calculated based on the transportation cost and fixed cost of four vehicles.

\section{RESULT AND DISCUSSION}

\section{A. Set Covering Problem}

Based on the set covering model, from all 10 candidate sub-districts, there were 2 alternative locations for emergency warehouses. There are Kalipucang and Parigi. These 2 alternatives can cover all the areas in Pangandaran Regency so that there is no need to build an emergency response warehouse in every sub-district to covers all demand. (Figure 4)

Based on the results of the Set Covering Problem model, the result of $\mathrm{X}=1$ is a warehouse to be built, vice versa. In this case, the solver used is Gurobi to solve simple problems such as linear programming.

\section{B. Analytical Network Process (ANP)}

The Analytical Network Process method aims to determine which sub-districts are more prioritised between Kalipucang and Parigi Districts.

Based on Table 4, it shows that Kalipucang District is the priority sub-district with a weight of 0.630224 . Based on Table 5, it shows that Kalipucang District is the priority sub-district with a weight of 0.60205 . To make sure the warehouse is on the right place based on several criterias, it is necessary to sort each criteria based on its priority. Table 6 shows the criteria priority result.

Based on the results of Table 6, the safer the area from the impact of the disaster gives the better result. Warehouse security is vital so that it can still functioned to send assistance when the disaster occurs in Pangandaran District.
After founds the optimal emergency warehouse location in the Kalipucang sub-district, the next step is to make a comparison between the Nearest Neighbor Heuristics, Local Search, and Simulated Annealing methods to find the best routes that can minimize travel time in delivering inventories from the emergency warehouse to the sub-districts that was affected by the disaster.

\section{Nearest Neighborhood Heuristics}

The distance needed to go through the route that is equal to $394 \mathrm{~km}$, with the time required is 6.567 hours. (Table 7)

\section{Local Search}

The distance needed to go through the route that is equal to $369 \mathrm{~km}$, with the time required is 6.15 hours. (Table 8)

\section{E. Simulated Annealing}

The distance needed to go through the route that is equal to $362 \mathrm{~km}$, with the time required is 6.033 hours. (Table 9)

\section{CONCLUSION}

Based on the results, it can be concluded that it is more effective and efficient to build 2 emergency warehouses, in Kalipucang and Parigi, which has been able to cover all demand in all sub-districts in Pengandaran. With the limitation of the government aims to build only 1 emergency warehouse, it was decided to build an emergency warehouse in Kalipucang based on the priority test. Kalipucang sub-district is a location for storing inventories, which can be said to be the starting point for delivering inventories. After comparing the Nearest Neighborhood Heuristics, Local Search, and Simulated Annealing, the most optimal route is showed with Simulated Annealing algorithm. The route are Warehouse - Kalipucang - Pangandaran Warehouse, Warehouse - Padaherang - Mangunjaya Warehouse, Warehouse - Parigi - Langkaplancar Cigugur - Warehouse, and Warehouse - Cijulang Cimerak - Sidamulih - Gudang. It has the shortest distance 
The 8th International Conference on Transportation \& Logistics (T-LOG 2020)

Surabaya September 6th-7th 2020, Universitas Internasional Semen Indonesia (UISI), Gresik, Indonesia

of $362 \mathrm{~km}$ with the required time is 6.033 hours. There are gaps in our knowledge around public involvement in our research, but from an academic perspective, there are recommendations for further research, including a simplified set covering model so that solve problems more efficiently, size of the Vehicle Routing Problem is only 10 customers and between Set Covering Problem and Vehicle Routing Problem can be solved independently because the connection among other seems weak.

\section{REFERENCES}

[1] S. Marlyono, "Perbandingan Tingkat Kesiapsiagaan Peserta Didik SD, SMP, dan SMA dalam Menghadapi Bencana Tsunami di Kecamatan Pangandaran Kabupaten Ciamis,” 2013.

[2] S. Purba, "Pemilihan Loker Otomatis sebagai Media
Pengumpulan Donasi Bencana Menggunakan Optimasi Dua Fase: P-Median dan VRP,” 2018.

[3] A. Kamil, H. Adzkia, and A. Redi, "Pemilihan Lokasi Parkir Penyewaan Sepeda Menggunakan Maximum Demand Covering Problem Studi Kasus: Kawasan Monas,” 2018.

[4] D. Priyanggo, U. Ciptomulyono, and P. Suwarno, “Analisis Penempatan Gudang Bantuan Omsp Tanggap Darurat Bencana Alam Menggunakan Set Covering Dan ANP (Studi Kasis di Kabupaten Cilacap)," in Prosising Seminar Nasional Pascasarjana STTAL, 2016.

[5] A. Malekinezhad, E. Shirazi, and M. Aryanezhad, "A Multi-Objective Set Covering Problem: a Case Study of Warehouse Allocation in Truck Industry,” Manag. Sci. Lett., vol. 1, no. 1, pp. 73-80, 2011.

[6] I. Suletra, W. Priyandari, and W. Jauhari, "Capacitated Set-Covering Model Considering the Distance Objective and Dependency of Alternative Facilities," in IOP Conference IOP Conference Series: Materials Science and Engineering, 2018. 